University of Nebraska - Lincoln

DigitalCommons@University of Nebraska - Lincoln

USDA National Wildlife Research Center - Staff Publications
U.S. Department of Agriculture: Animal and Plant Health Inspection Service

2012

\title{
Assessment of toxicity and potential risk of the anticoagulant rodenticide diphacinone using Eastern screech-owls (Megascops asio)
}

\author{
Barnett A. Rattner \\ U.S. Geological Survey, brattner@usgs.gov \\ Katherine E. Horak \\ USDA/APHIS/WS National Wildlife Research Center, katherine.e.horak@aphis.usda.gov \\ Rebecca S. Lazarus \\ U.S. Geological Survey \\ Karen M. Eisenreich \\ U.S. Geological Survey \\ Carol U. Meteyer \\ U.S. Geological Survey, cmeteyer@usgs.gov
}

See next page for additional authors

Follow this and additional works at: https://digitalcommons.unl.edu/icwdm_usdanwrc

Rattner, Barnett A.; Horak, Katherine E.; Lazarus, Rebecca S.; Eisenreich, Karen M.; Meteyer, Carol U.; Volker, Steven F.; Campton, Christopher M.; Eisemann, John D.; and Johnston, John J., "Assessment of toxicity and potential risk of the anticoagulant rodenticide diphacinone using Eastern screech-owls (Megascops asio)" (2012). USDA National Wildlife Research Center - Staff Publications. 1186.

https://digitalcommons.unl.edu/icwdm_usdanwrc/1186

This Article is brought to you for free and open access by the U.S. Department of Agriculture: Animal and Plant Health Inspection Service at DigitalCommons@University of Nebraska - Lincoln. It has been accepted for inclusion in USDA National Wildlife Research Center - Staff Publications by an authorized administrator of DigitalCommons@University of Nebraska - Lincoln. 


\section{Authors}

Barnett A. Rattner, Katherine E. Horak, Rebecca S. Lazarus, Karen M. Eisenreich, Carol U. Meteyer, Steven F. Volker, Christopher M. Campton, John D. Eisemann, and John J. Johnston 


\title{
Assessment of toxicity and potential risk of the anticoagulant rodenticide diphacinone using Eastern screech-owls (Megascops asio)
}

\author{
Barnett A. Rattner - Katherine E. Horak - Rebecca S. Lazarus • \\ Karen M. Eisenreich - Carol U. Meteyer - Steven F. Volker • \\ Christopher M. Campton · John D. Eisemann · John J. Johnston
}

Accepted: 15 December 2011/Published online: 8 January 2012

(C) Springer Science+Business Media, LLC (outside the USA) 2012

This article is a U.S. government work, and is not subject to copyright in the United States.

\begin{abstract}
In the United States, new regulatory restrictions have been placed on the use of some second-generation anticoagulant rodenticides. This action may be offset by expanded use of first-generation compounds (e.g., diphacinone; DPN). Single-day acute oral exposure of adult Eastern screech-owls (Megascops asio) to DPN evoked overt signs of intoxication, coagulopathy, histopathological lesions (e.g., hemorrhage, hepatocellular vacuolation), and/ or lethality at doses as low as $130 \mathrm{mg} / \mathrm{kg}$ body weight, although there was no dose-response relation. However, this single-day exposure protocol does not mimic the multiple-day field exposures required to cause mortality in rodent pest species and non-target birds and mammals. In 7-day feeding trials, similar toxic effects were observed in owls fed diets containing $2.15,9.55$ or $22.6 \mathrm{ppm}$ DPN, but at a small fraction $(<5 \%)$ of the acute oral dose. In the
\end{abstract}

Electronic supplementary material The online version of this article (doi:10.1007/s10646-011-0844-5) contains supplementary material, which is available to authorized users.

B. A. Rattner $(\bowtie)$. R. S. Lazarus · K. M. Eisenreich

Patuxent Wildlife Research Center, U.S. Geological Survey, c/o Beltsville Agricultural Research Center-East, Building 308 10300 Baltimore Avenue, Beltsville, MD 20705, USA

e-mail: brattner@usgs.gov

K. E. Horak · S. F. Volker - C. M. Campton · J. D. Eisemann U.S. Department of Agriculture, National Wildlife Research Center, Fort Collins, CO 80521, USA

C. U. Meteyer

U.S. Geological Survey, National Wildlife Health Center, Madison, WI 54603, USA

J. J. Johnston

U.S. Department of Agriculture, Food Safety and Inspection

Service, Fort Collins, CO 80521, USA dietary trial, the average lowest-observed-adverse-effectlevel for prolonged clotting time was $1.68 \mathrm{mg}$ DPN/kg owl/week (0.24 mg/kg owl/day; $0.049 \mathrm{mg} / \mathrm{owl} /$ day $)$ and the lowest lethal dose was $5.75 \mathrm{mg} \mathrm{DPN} / \mathrm{kg}$ owl/week $(0.82 \mathrm{mg} / \mathrm{kg}$ owl $/$ day $)$. In this feeding trial, DPN concentration in liver ranged from 0.473 to $2.21 \mu \mathrm{g} / \mathrm{g}$ wet weight, and was directly related to the daily and cumulative dose consumed by each owl. A probabilistic risk assessment indicated that daily exposure to as little as $3-5 \mathrm{~g}$ of liver from DPN-poisoned rodents for 7 days could result in prolonged clotting time in the endangered Hawaiian shorteared owl (Asio flammeus sandwichensis) and Hawaiian hawk (Buteo solitarius), and daily exposure to greater quantities (9-13 g of liver) could result in low-level mortality. These findings can assist natural resource managers in weighing the costs and benefits of anticoagulant rodenticide use in pest control and eradication programs.

Keywords Rodenticides - Birds · Clotting time · Diphacinone $\cdot$ Secondary poisoning

\section{Introduction}

Anticoagulant rodenticides have been reported to be hazardous to predatory and scavenging birds on a worldwide scale (e.g., Canada: Howald et al. 1999; Albert et al. 2009; France: Lambert et al., 2007; Great Britain: Walker et al. 2008; New Zealand: Eason and Spurr 1995; Eason et al. 2002; United States: Stone et al. 1999, 2003; Lima and Salmon 2010). In extreme situations, such as rodent eradication operations, non-target avian mortality and even population-level effects can occur through direct ingestion of rodenticide-containing bait and by consumption of poisoned prey. For example, brodifacoum-based baits resulted 
in $>80 \%$ reductions in woodhen (Gallirallus australis) populations and loss of some raptors (e.g., Australasian harrier, Circus approximans; morepork, Ninox novaeseelandiae) at Stewart, Ulva and Inner Chetwode Islands in New Zealand (Eason and Spurr 1995; Eason et al. 2002). Recently, carcasses of 320 glaucous-winged gulls (Larus glaucescens) and 46 bald eagles (Haliaeetus leucocephalus) were recovered following a rodent eradication project using brodifacoum 25-W bait on Rat Island in Alaska (The Ornithological Council 2010). The magnitude of non-target wildlife poisoning from both routine use and pest eradication programs is unknown. Despite short-term adverse effects on non-target wildlife, rodent eradication programs can certainly be beneficial, and lead to the recovery of native populations of birds and other species (Towns and Broome 2003; Whitworth et al. 2005; Lock 2006; Smith et al. 2006).

Exposure and toxicity data for nine rodenticides were examined by the U.S. Environmental Protection Agency (USEPA) (Erickson and Urban 2004), and several secondgeneration anticoagulant rodenticides (SGARs) that can kill target species in a single feeding were identified as a potentially significant risk to birds and non-target mammals. Focusing on residential use, the USEPA instituted restrictions on the sale, distribution, and packaging of some SGARs (i.e., brodifacoum, difethialone, bromadiolone, difenacoum), and required more protective bait stations (USEPA 2006, 2008). This action will likely result in expanded use of first-generation anticoagulant rodenticides (FGARs), that are considered to be less hazardous to non-target wildlife than SGARs (Erickson and Urban 2004; Shlosberg and Booth 2006; Baldwin and Salmon 2011). Nonetheless, even FGARs like diphacinone have been implicated in mortality events involving raptors (e.g., snowy owl, Nyctea scandiaca; Stone et al. 1999), and detected but not definitely implicated in others (e.g., red-tailed hawk, Buteo jamaicensis, Cooper's hawk, Accipiter cooperii, barn owl, Tyto alba; Stone et al. 2003; Pitt et al. 2005). Recent acute toxicity studies in the American kestrel (Falco sparverius) demonstrated that they are 20-30 times more sensitive to diphacinone (DPN) than the Northern bobwhite (Colinus viginianus) and mallard (Anas platyrhynchos) that are traditionally used in avian toxicity studies for chemical registration (Rattner et al. 2010a, 2011). A preliminary risk assessment suggests that this FGAR may pose a more significant risk to some raptors than previously realized (Rattner et al. 2011).

The present study was conducted to evaluate overt toxicity, histopathology and blood clotting time responses, and tissue residue concentrations following DPN administration to Eastern screech-owls (Megascops asio), a member of the order Stringiformes that has been used extensively in raptor toxicological studies (Wiemeyer 2010). These data, in combination with similar information in Northern bobwhite and American kestrels are being used to develop a pharmacodynamic model and a more complete risk assessment of the toxicity of DPN in birds.

\section{Materials and methods}

Animals

All animal procedures were approved by the Institutional Animal Care and Use Committee of the Patuxent Wildlife Research Center. Eastern screech-owls, propagated from the captive colony at Patuxent, were reared in vinyl-coated wire outdoor flight pens $(6.1 \mathrm{~m}$ long $\times 2.4 \mathrm{~m}$ wide $\times$ $2.1 \mathrm{~m}$ high) containing a nest box, several perches, feed tray and a bowl of fresh water (Wiemeyer 1987). Birds from the captive colony were maintained on daily rations of dead laboratory mice (Mus musculus), dead chicken (Gallus gallus) hatchlings, or Classic Bird of Prey diet (Nebraska Brand, North Platte, NE) supplemented with Vionate $^{\circledR}$ (Gimborn US, Atlanta, GA). Because screechowls are not sexually dimorphic, sex was determined by gene amplification (CHD1-Z and CHD1-W) using realtime PCR analysis (Brubaker et al. 2011), and results were all confirmed at necropsy.

For toxicity studies, owls were moved from flight pens to small outdoor cages $(1.2 \mathrm{~m}$ long $\times 0.8 \mathrm{~m}$ wide $\times 0.6 \mathrm{~m}$ high) with a shade roof, rope perch, wooden perch box, food tray and water bowl, where they were housed individually. Birds were acclimated to these pens for at least 2 weeks. An acute toxicity study was conducted between September 15 and October 13, 2010 (ambient temperature: $\left.7-34^{\circ} \mathrm{C}\right)$ using 19 adult owls (10 males, 9 females; 2-9 years old) with an average body weight of $165.3 \mathrm{~g}$ (extremes: 130-190 g). A 7-day feeding trial was conducted between November 22 to December 7, 2010 (ambient temperature: $\left.-3-19^{\circ} \mathrm{C}\right)$ using 21 adult owls $(10$ males, 11 females; 2-6 years old) with an average body weight of $191.4 \mathrm{~g}$ (extremes: 157-254 g). In both studies, the distribution of sexes among dose groups was approximately equal. Efforts were made to minimize the number of test subjects used in these two toxicity studies without compromising a robust experimental design.

Acute single-day oral dose toxicity of diphacinone

We attempted to use the dosing scheme similar to that used with American kestrels (Rattner et al. 2011). In preliminary studies, owls were administered size 3 or size 
4 gelatin capsules (E. Lilly and Company, Indianapolis, IN) containing freeze-dried Classic Bird of Prey diet and $5 \mu \mathrm{l}$ FD\&C Blue \#1 food dye (marker for regurgitation; McCormick \& Co., Baltimore, MD), but no DPN, to the level of the proventriculus followed by $0.2 \mathrm{ml}$ distilled water. This sham-dosing occurred in the afternoon or early evening (1500-2000 h) after which owls were offered a dead mouse. The following morning, inspection of the kraft paper lining the pen for regurgitated dye or remains of a capsule indicated that the sham dose was retained by the owls. However, upon inclusion of neat DPN [2-(diphenylacetyl)indan-1,3-dione; CAS 82-66-6; 99.2\% purity] (Hacco, Inc., Randolph, WI) in size 4 capsules (35.1, 52.7, 79.0 and $177.9 \mathrm{mg} / \mathrm{kg}$ administered as a divided dose at 1600 and $2000 \mathrm{~h}$ ), post-dose examination of the kraft paper revealed that all owls receiving DPN regurgitated a portion of the administered dose within $24 \mathrm{~h}$. Attempts at varying the original dosing scheme (e.g., omission of distilled water chaser, varying time of dosing and duration of fasting, minimizing size of cast pellets by feeding Classic Bird of Prey diet followed by skinned mice at dosing, or splitting dose into 4 capsules) did not prevent regurgitation of DPN. Based upon the inability to prevent regurgitation of orally administered neat DPN, we collected the areas of kraft paper containing Blue \#1 dyestained fragments of regurgitated capsules, neat DPN and castings, and quantified the amount of DPN in these materials to estimate the fraction of the nominal dose retained by each owl.

In a subsequent larger trial conducted over a 4-week period, owls were maintained on small mice for one week, fasted for $24 \mathrm{~h}$, and administered a divided dose of DPN in gelatin capsules (size 3 or 4) over a 24-h period (dosing at $0900,1300,1700 \mathrm{~h}$, fed mice and then dosed again at $0800 \mathrm{~h}$ the following morning). A total of 15 owls received DPN doses of $266,400,600,900$ or $1,450 \mathrm{mg} / \mathrm{kg}$, and 4 owls served as sham-dosed controls. Portions of kraft paper containing regurgitate and cast pellets were collected for 4 days following dosing, and stored at $-20^{\circ} \mathrm{C}$ for chemical analysis to estimate the retained dose. Birds were observed 3 times each day, and weighed and examined on days 2, 4 and 6 . Individuals that died during the trial were necropsied within 4-12 h. Seven days after administration of the final capsule, survivors were weighed and bled by jugular venipuncture $(0.9 \mathrm{ml}$ sample collected into a $1 \mathrm{ml}$ syringe containing $0.1 \mathrm{ml}$ of $3.2 \%$ sodium citrate; Sigma-Aldrich, St. Louis, MO). Each blood sample was centrifuged ( $2000 \mathrm{~g}$ for $5 \mathrm{~min}$ ), and the citrated plasma was harvested and divided into 3 vials that were stored at $-80^{\circ} \mathrm{C}$ for clotting assays. Survivors were then euthanized with carbon dioxide and necropsied. Portions of heart, liver, kidney, lung, spleen, intestine, brain, skeletal muscle and occasionally other tissues were fixed in phosphate buffered formalin for histopathological analysis, and the remainder of the liver was frozen at $-20^{\circ} \mathrm{C}$ for residue analysis.

\section{Short-term dietary toxicity of diphacinone}

Diphacinone solutions were prepared by dissolving varying quantities of neat material in $5 \mathrm{ml}$ of acetone, and diluting stock solutions with corn oil $(1: 10)$ to yield nominal concentrations of 0 (control), $0.25 \mathrm{mg}, 1.0 \mathrm{mg}$ and $2.5 \mathrm{mg}$ DPN/ml. These solutions were mixed into Classic Bird of Prey diet (supplemented with Vionate ${ }^{\circledR}$ ) at a ratio of 1:100, and then placed in a fume hood to allow the acetone to evaporate. After $30 \mathrm{~min}$, the diets were mixed for another $5 \mathrm{~min}$ and placed in a fume hood for another $30 \mathrm{~min}$, after which there was no detectable odor of acetone. Treated diets containing nominal concentrations of $0,2.5,10$ and $25 \mathrm{ppm}$ DPN were formed into meatballs weighing $25.0 \pm 0.1 \mathrm{~g}$, and stored at $-20^{\circ} \mathrm{C}$.

A jugular venipuncture sample was collected from all owls 10 days before the initiation of the DPN feeding trial. During the pre-trial period, owls were weighed, fed untreated Classic Bird of Prey diet for 7 days, and reweighed after 3 and 7 days. It was noted that a few birds ( $n=3$ of 24) refused to consume this diet, and were excluded from the feeding trial. Owls were then provided two treated meatballs daily for 7 days. There were 5 individuals designated to the control $(0 \mathrm{ppm}), 2.5$ and $10 \mathrm{ppm}$ treatments, and 6 owls in the $25 \mathrm{ppm}$ treatment group, with sexes divided nearly equally or equal. Uneaten meatball scraps were collected from the kraft paper lined pens at $24 \mathrm{~h}$ intervals at the time of feeding $(1600-1700 \mathrm{~h})$ in order to estimate the amount of DPN consumed. During the feeding trial, owls were observed three times daily (0700-0800, 1200-1300, 1600-1700 h), weighed and examined on days 0,4 and 7 , and survivors were bled, euthanized and necropsied as described in the acute toxicity study. Microhematocrit was determined on a small volume of the blood sample, and values were adjusted for the volume of the sodium citrate anticoagulant.

Diphacinone consumption was estimated by obtaining the dry weight mass of uneaten scraps for each owl. Briefly, whole uneaten meatballs, and meatball scraps for each owl for the 7 day period, were transferred to preweighed aluminum pans and dried at $105^{\circ} \mathrm{C}$ (Fisher Scientific Isotemp Oven, Model 630F, Pittsburgh, PA) for $24 \mathrm{~h}$. Each pan was transferred to a desiccator and allowed to cool for $30 \mathrm{~min}$. A subset of samples were dried a second time, and weight change was $<0.15 \%$ that verified the initial dry weight. Percent moisture and dry weight of 14 uneaten $25 \mathrm{~g}$ meatballs were determined, used to convert the weight of dried scraps to wet weight, and used to to 
estimate food and DPN consumption over the 7 day treatment period.

\section{Histopathology}

In the acute and short-term dietary exposure studies, formalin fixed tissues were processed (American HistoLabs, Gaithersburg, MD) using standard procedures (Luna 1968). In general, two $4 \mu \mathrm{m}$ sections per tissue, in steps of $100 \mu \mathrm{m}$, were mounted on slides and stained with hematoxylin and eosin, and examined by light microscopy.

Diphacinone purity, and concentrations in regurgitate, treated diet, and liver

The purity of neat DPN was determined (Rattner et al. 2011) by reversed phase ion-paired high-performance liquid chromatography (RP-HPLC) with UV detection at $285 \mathrm{~nm}$ and found to be $99.2 \%$ (w/w). In the acute toxicity study, the castings and regurgitant (including portions of the kraft cage paper) were collected in a single container and stored at $-20^{\circ} \mathrm{C}$. The contents of the container were quantitatively transferred into a MARSXpress 55-ml Teflon digestion vessel and $40 \mathrm{ml}$ of acetonitrile added. The samples were thoroughly vortex mixed before and after extraction at $125^{\circ} \mathrm{C}$ for $60 \mathrm{~min}$ using a using a microwave accelerated reaction system (MARS, CEM Corp, Matthews, NC). A portion of the extract was filtered though a $0.7-\mu \mathrm{m}$ glass fiber syringe filter (Whatman Inc., Sanford, ME) and diluted 1:10 with acetonitrile. A $30 \mu \mathrm{l}$ aliquot of the diluted sample was combined with $1.5 \mathrm{ml}$ of Mobile Phase A (tetrabutylammonium dihydrogen phosphate (TBAP, Sigma-Aldrich) methanolic solution) (Supplemental Material, Supplemental Table 1) in an HPLC vial prior to analysis. Concentrations of DPN were determined using an Agilent 1100 series HPLC system with a variable wave length detector (Agilent Technologies, Santa Clara, CA) and Luna $\mathrm{C} 18(2), 3.0 \times 150-\mathrm{mm}, 3-\mu \mathrm{m}$ column (Phenomenex Inc., Torrance, CA) according to the parameters described in Supplemental Table 1. All samples were within the seven-point standard curve ranging from 0.004 to $6.1 \mu \mathrm{g} \mathrm{DPN} / \mathrm{ml}\left(R^{2}=0.999\right)$. A control sample prepared with Bird of Prey diet (including kraft paper) and fortified with $0.61 \mathrm{mg}$ DPN produced a recovery of $95 \%$.

For the DPN feeding study, 60-90 mg of each DPNcorn oil solution was weighed into a glass tube and dissolved in 1:1 acetone/chloroform. A $0.5 \mathrm{ml}$ portion of each solution was transferred to separate tubes and reduced to dryness with $\mathrm{N}_{2}$ in an N-Evap heated to $60^{\circ} \mathrm{C}$. The residues were reconstituted in $10 \mathrm{ml}$ of diluent (4:1 mobile phase $\mathrm{A} / \mathrm{B})$ and assayed for diphacinone content by RP-HPLC using a Gemini C18, $3.0 \times 150-\mathrm{mm}, 3-\mu \mathrm{m}$ column (Phenomenex) according to the parameters described in
Supplemental Table 1. Recovery of DPN (mean \pm SD, triplicate determinations) from nominal corn oil solutions $(0.25,1.0$ and $2.5 \mathrm{mg} / \mathrm{ml})$ ranged from $90.2 \pm 2.8 \%$ to $97.6 \pm 1.6 \%$.

To determine the concentration of DPN in fortified Classic Bird of Prey diet, meatballs were homogenized in a SPEX CertiPrep 6850 Liquid Nitrogen Freezer Mill (SPEX Certiprep Group, LLC, Metuchen, NJ) and 0.25-0.30 g of the homogenized material was accurately weighed directly into a MARSXpress digestion vessel. Chlorophacinone was added as the surrogate. Four $\mathrm{ml}$ of $0.5 \%$ trifluoroacetic acid in 1:1 acetonitrile:chloroform was added followed by $1.5 \mathrm{~g}$ of anhydrous sodium sulfate. Each sample was vortexed briefly and microwave extracted by heating to $120^{\circ} \mathrm{C}$ over $5 \mathrm{~min}$, held for $15 \mathrm{~min}$, and cooled to room temperature. Samples were then briefly vortex mixed, centrifuged, and the supernatant was removed. Each sample was extracted by this method two additional times and the supernatants pooled. Each sample was reduced to dryness under $\mathrm{N}_{2}$ in an $\mathrm{N}$-Evap heated to $60^{\circ} \mathrm{C}$. The residues were reconstituted in $3 \mathrm{ml}$ of chloroform, vortex mixed, and sonicated for $10 \mathrm{~min}$. Three $\mathrm{ml}$ of hexanes was added and the samples were again vortex mixed and sonicated for $5 \mathrm{~min}$, followed by filtration through $0.7-\mu \mathrm{m}$ glass fiber syringe filters. The filtrates were cleaned-up using $200 \mathrm{mg} / 3 \mathrm{ml}$ Strata-X-AW Weak Anion Exchange SPE cartridges (Phenomenex). Each SPE cartridge was conditioned with $3 \mathrm{ml}$ of a 46:54 chloroform:hexanes solution. The samples were loaded onto the SPE cartridge, washed with $3 \mathrm{ml}$ of $46: 54$ chloroform:hexanes, and eluted with a 15-mM TBAP methanolic solution. The eluates were reduced to dryness under $\mathrm{N}_{2}$ at $60^{\circ} \mathrm{C}$ and reconstituted in diluent (40\% 5-mM TBAP in $\mathrm{pH} 8.56-\mathrm{mM}$ phosphate buffer/60\% methanol). Samples were filtered directly into HPLC vials using $0.45-\mu \mathrm{m}$ PTFE syringe filters (National Scientific, Rockwood, TN) and analyzed by RP-HPLC using a Gemini C18, $3.0 \times 150$ $\mathrm{mm}, 3-\mu \mathrm{m}$ column (Phenomenex) according to the parameters described in Supplemental Table 1. Recovery of DPN (triplicate determinations) from fortified meatballs (nominal concentrations of 2.5, 10 and $25 \mu \mathrm{g} / \mathrm{g}$ wet weight) ranged from $86.1 \pm 12.3 \%$ to $95.5 \pm 5.6 \%$.

Screech-owl liver samples from the acute and dietary feeding studies were quantified as recently described in detail (Rattner et al. 2011). Briefly, liver tissue was homogenized, extracted with acetonitrile using a MARS, filtered, cleaned with solid phase extraction cartridges, and eluted with methanolic solution containing $15 \mathrm{mM}$ TBAP (Supplemental Table 1). The eluate was dried, reconstituted in mobile phase, and filtered into vials for DPN quantification by RP-HPLC. The recovery of DPN and surrogate (chlorophacinone) from spiked control samples $(n=6)$ was $99.1 \pm 2.9 \%$ and $86.9 \pm 3.4 \%$. The method limits of detection and quantification from three separate 
assays averaged $0.123 \pm 0.060 \mu \mathrm{g} / \mathrm{g}$ and $0.410 \pm 0.202$ $\mu \mathrm{g} / \mathrm{g}$, respectively.

\section{Clotting time assays}

Prothrombin time (PT) and Russell's viper venom time (RVVT) of citrated plasma samples were used to evaluate effects of the DPN on post-translational processing of clotting Factors II, VII, IX and X. Thrombin clotting time (TCT) was used to verify sample quality (i.e., fibrinogen concentration $>65 \mathrm{mg} / \mathrm{dl}$ ) that can be compromised by improper collection technique, and to exclude nonspecific influences on clotting (e.g., hepatic synthetic failure, disseminated intravascular coagulation). Clotting time was determined using a BBL fibrometer (Becton-Dickinson \& Co., Baltimore, MD). Assay methods and performance characteristics in human, bobwhite quail (Colinus virginianus) and American kestrel samples have recently been described (Rattner et al. 2010b, 2011).

For screech-owls, the PT assay was modified by further diluting chick hatchling brain thromboplastin 1:8 with $25 \mathrm{mM} \mathrm{CaCl}_{2}$ (Fig. 1a) and plasma samples were diluted $(60 \mu \mathrm{l}$ plasma $+40 \mu \mathrm{l} 8.3 \mathrm{mM}$ phosphate buffer) without appreciable effect on clotting time (Fig. 1b). The coefficient of variation $\pm \mathrm{SD}$ for duplicate determinations of samples with clotting time $<100 \mathrm{~s}$ was $6.5 \pm 6.3 \%$ ( $n=44)$, but at $>100 \mathrm{~s}$ (extreme coagulopathy) precision deteriorated to $41.7 \pm 47.8 \% \quad(n=8)$. For the RVVT assays, plasma samples were also diluted with phosphate buffer (70:30) without effect on clotting time (Fig. 1c). The coefficient of variation \pm SD for duplicate determinations of samples with RVVT $<100 \mathrm{~s}$ was $1.5 \pm 1.2 \%(n=34)$, and at $>100 \mathrm{~s}$ (extreme coagulopathy) precision was $9.5 \pm 15.7 \%(n=13)$. In the TCT assay, precision of duplicate determinations was $1.9 \pm 3.2 \%(n=44)$.

\section{Statistical and risk analyses}

A one-phase exponential decay model (Prism, GraphPad Software, La Jolla, CA) was used to describe the relation between clotting time (PT and RVVT) and dilution of owl plasma. For the acute toxicity trial, the relation between the administered dose and retention of DPN in the owls was examined by simple linear regression, and the relations between both administered dose and retained dose with signs of intoxication/mortality were evaluated using probit analysis (SAS version 9.2, SAS Institute, Carey, NC). In the short-term dietary exposure trial, body weight change, liver to body weight ratio, PT, RVVT, TCT, and DPN residues in liver were tested for homogeneity of variances $\left(F_{\max }\right.$ test) and normality (Shapiro-Wilk test, normal probability plot and descriptive statistics). Measurement endpoints were tested by one-way analysis of variance, and

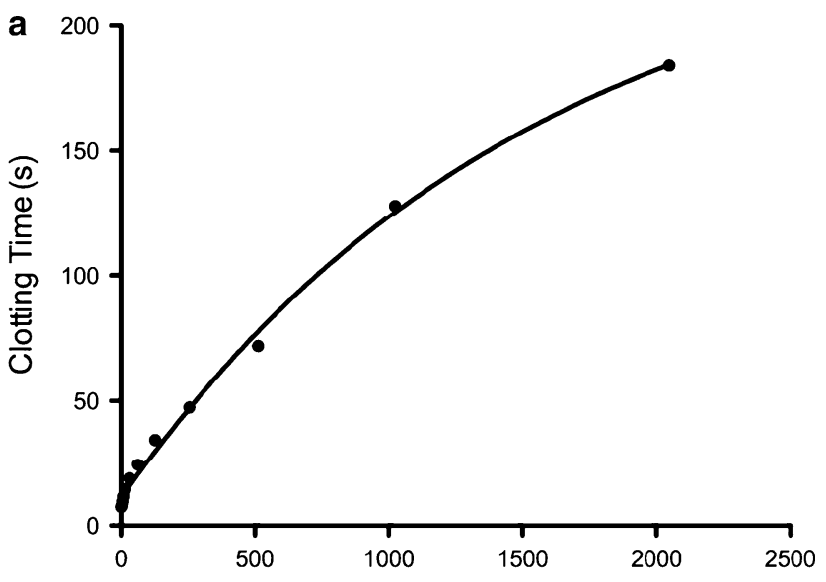

Fold Dilution of Chicken Hatchling Brain Thromboplastin
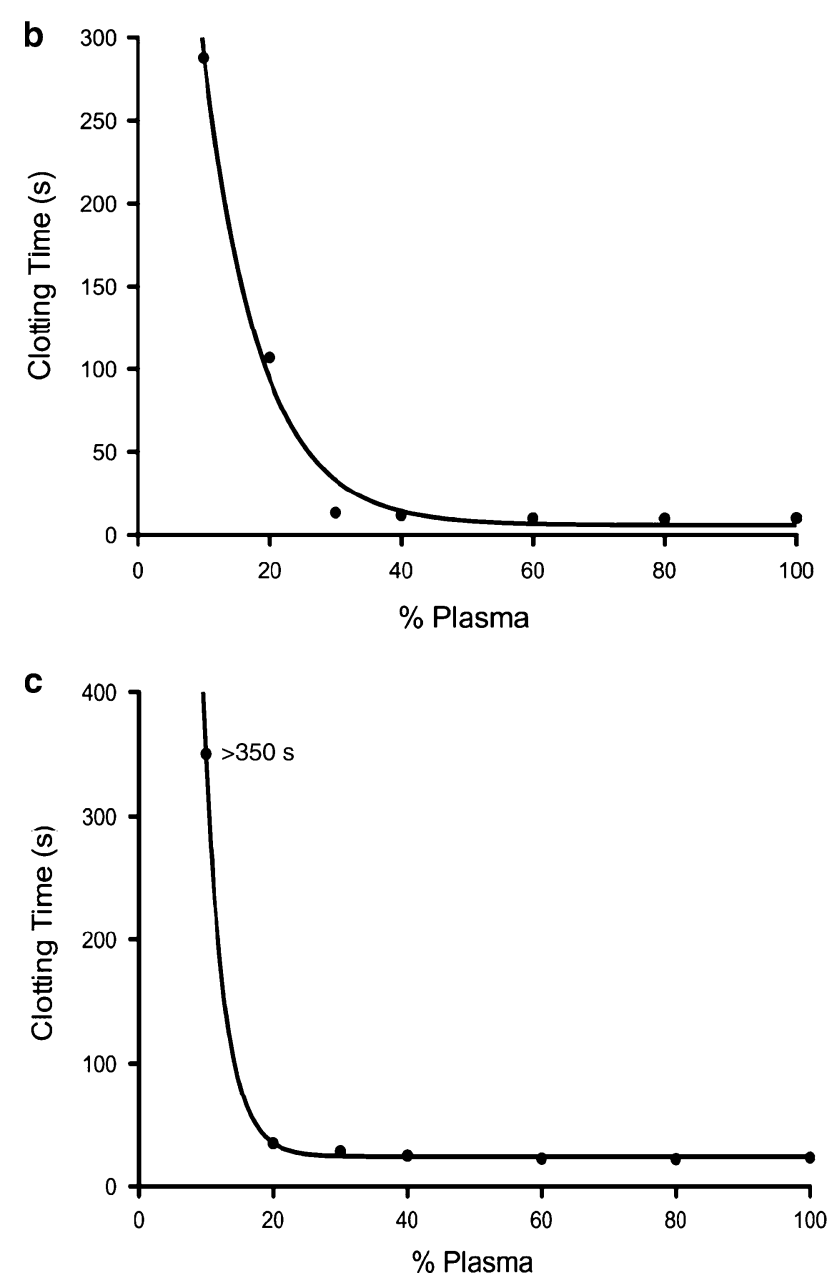

Fig. 1 a Clot promoting potential (prothrombin time) of undiluted and diluted (1:2-1:2048) chicken hatchling thromboplastin incubated with citrated Eastern screech-owl plasma $\left(Y=246.6-235.5 \mathrm{e}^{-0.00065(\text { thromboplastin dilution) }} ; R^{2}=0.97\right) ; \quad b$ effect of diluting citrated Eastern screech-owl plasma with phosphate buffer $(100,80,60,40,20$, and $10 \%$ plasma) on prothrombin time $\left(Y=5.84+916.4 \mathrm{e}^{-0.1171(\% \text { plasma })} ; R^{2}=0.99\right) ; \mathbf{c}$ effect of diluting citrated Eastern screech-owl plasma with phosphate buffer $(100,80$, $60,50,40,30,20$, and $10 \%$ plasma) on Russell's viper venom time $\left(Y=24.53+9706 \mathrm{e}^{-0.3393(\% \text { plasma })} ; R^{2}=0.99\right)$ 
clotting time of DPN treated-owls (hours post-dose) were compared using Tukey's HSD test. The relation between dose, hematocrit and DPN residues in liver was examined by linear regression.

Based upon responses (e.g., prolonged clotting time, reduced hematocrit, lethality) in the short-term dietary toxicity study, the lowest-observed-adverse-effect-level and the lowest lethal dose was estimated and used to predict potential risk thresholds using a deterministic exposure model (Eisemann and Swift 2006). In addition, a probabilistic-based exposure model was developed using Crystal Ball Software (Oracle Inc., Redwood City, CA) and used to estimate the quantity of rodent liver consumption that would be required to exceed various toxicological endpoints (Johnston et al. 2005). For each iteration, a single value was Monte-Carlo sampled from each model input distribution. The result of each iteration was integrated across one million iterations to estimate the range and frequency of rodent liver consumption estimates for populations of avian non-targets. This evaluation incorporated the distributions of body weights and liver DPN concentrations to generate consumption estimate distributions and their associated probabilities.

\section{Results}

Acute single day oral dose toxicity of diphacinone

The 4 sham-dosed control screech-owls appeared normal and survived the 7-day trial, while 8 of 15 DPN-dosed owls exhibited overt signs of toxicity (e.g., ataxia, unresponsive to external stimuli, appearance of subcutaneous bruising along featherless tract of the neck-Fig. 2a versus $2 b$, ocassional frank blood on feathers or paper lining the pen) and evidence of hemorrhage at necropsy (e.g., dappling or blood clots on breast muscle, liver, lung, and in the peritoneal cavity; pallor along the gastrointestinal tract and liver). Histological lesions (e.g., hepatocellular vacuolation and swelling, cytoplasmic vacuolation of renal convoluted tubules, and occasional hemorrhage in skeletal muscle, Fig. 2c) were present in some, but not all of the DPN-dosed birds. Three of the eight affected birds, plus an additional owl that received $1,450 \mathrm{mg} / \mathrm{kg}$, died between days 2 and 5 of the trial. There was no relation between administered dose and death (probit analysis, $p>0.9$ ), and there was no relation between administered dose and overt toxicity (i.e., respondent classified as exhibiting overt signs of intoxication, hemorrhage at necropsy and/or death; probit analysis, $p>0.75$ ) (Table 1). Toxicity appeared to be similar between sexes.

In contrast to the controls that retained gelatin capsules containing freeze-dried food, about half of the administered dose (mean $\pm \mathrm{SD}, 52.6 \pm 14.0 \%$ ) was regurgitated by the 15 owls that received capsules containing DPN (266-1,450 mg/kg body weight). The fraction (\%) of administered DPN dose that was regurgitated was not dependent on the quantity of DPN that was administered $(p>0.23)$. As the administered dose increased, owls retained progressively more DPN $\left(p<0.0001, R^{2}=0.73\right)$ (Fig. 3). However, there was no evidence of a relation between retained dose and overt toxicity (probit analysis, $p>0.8$ ). At retained doses below $350 \mathrm{mg} / \mathrm{kg}$ (i.e., $130-275 \mathrm{mg} / \mathrm{kg}$ ) 4 of 7 owls were classified as respondents, and at retained doses above $350 \mathrm{mg} / \mathrm{kg}$ (i.e., $402-718 \mathrm{mg} /$ $\mathrm{kg}) 5$ of 8 were respondents (Fig. 3). In preliminary trials, there were no signs of intoxication at administered doses ranging from 35 to $177.9 \mathrm{mg} / \mathrm{kg}$. Inspection of these data did not indicate that there was any difference in sensitivity between male and female owls.

Body weight change over the 7-day trial was not related to retained dose $(p>0.15)$, although weight loss of the 4 owls that died $(-10.0$ to $-24.0 \mathrm{~g} / 100 \mathrm{~g}$ initial body weight) was pronounced compared to weight change of the survivors ( -6.4 to $+11.9 \mathrm{~g} / 100 \mathrm{~g}$ initial body weight), and owls that were necropsied were found to have adequate fat and pectoral muscling. Citrated blood samples were collected from survivors 7 days (168 h) after DPN administration, presumably long after peak effects on clotting time (Rattner et al. 2010a, 2011). Nonetheless, clotting times of dosed owls were often prolonged compared to controls (Table 1), and there was a significant relation when regressed with retained dose $\left(p<0.025, R^{2}\right.$ for PT and RVVT were 0.44 and 0.62 , respectively). Fibrinogen concentration ranged from 65.7 to $232.5 \mathrm{mg} / \mathrm{dl}$ in all but one sample $(900 \mathrm{mg} / \mathrm{kg}$ dose; no fibrinogen detected suggesting the sample was compromised, and thus excluded from the data set; see Rattner et al. 2010b).

Diphacinone was detected in the liver of all dosed owls, but was not present in the single control bird that was euthanized at the end of the trial. Of the 11 DPN-dosed survivors, concentrations in liver after 7 days ranged between 0.24 and $0.70 \mu \mathrm{g} / \mathrm{g}$ wet weight, while in the owls that died between days 2 and 5 levels ranged from 0.95 to $61.9 \mu \mathrm{g} / \mathrm{g}$ (extreme value from bird that succumbed on day 2).

Short-term dietary toxicity of diphacinone

Analytical recovery of DPN from diets with nominal concentrations of $2.5,10$ and 25 ppm averaged $86.1 \pm 12.28 \%$, $95.5 \pm 5.60 \%$ and $90.4 \pm 2.87 \%$, respectively. Thus, the mean measured quantities of DPN fed to owls were estimated to be dietary quantities of 2.15, 9.55 and $22.6 \mathrm{ppm}$.

During the 7-day feeding trial, control screech-owls appeared normal and were in good fat and flesh condition 

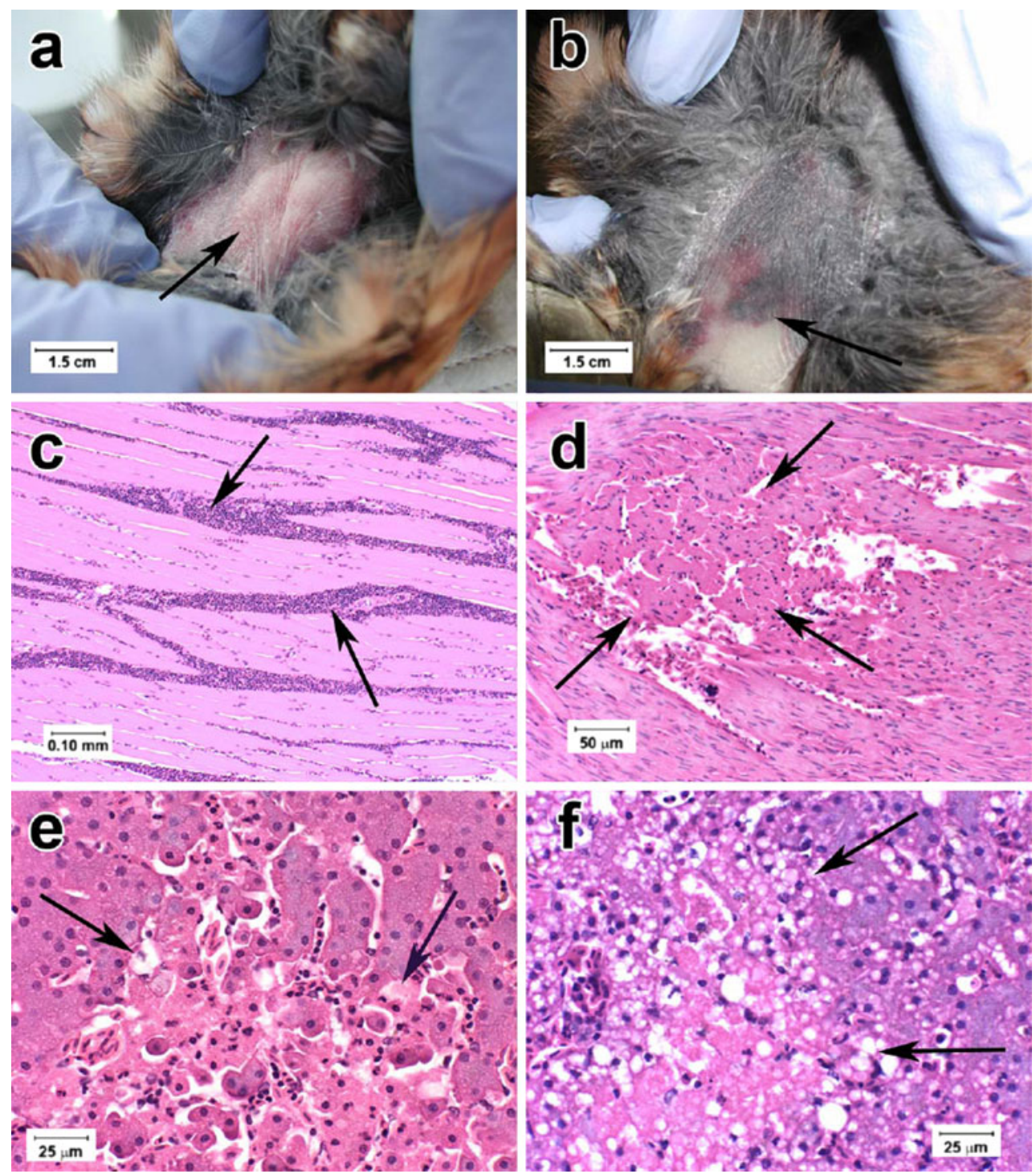

Fig. 2 a Featherless tract on neck of control Eastern screech-owl; b appearance of bruising on featherless tract of DPN-dosed screechowl that had not be bled in several weeks; c skeletal muscle hemorrhage in a screech-owl that retained an acute DPN dose of $587 \mathrm{mg} / \mathrm{kg}$; d myocardial hemorrhage and signs of early cell death characterized by hypereosinophilic myocytes containing with

at necropsy (Table 2). Owls consumed a cumulative dose ranging from 0.281 to $3.85 \mathrm{mg}$ DPN during the trial, with exposure differing among groups $(p<0.05)$ (Table 2$)$. These birds exhibited dose-related signs of intoxication (e.g., indication of hemorrhage, bruising, subdued behavior). Although they were in good body condition at necropsy, there was additional evidence of subcutaneous bruising and blood loss. Of the six owls fed $22.6 \mathrm{ppm}$ DPN, one was found dead during the afternoon of day 5 and another was found dead during the morning of day 7 . Histological examination of owls ingesting DPN revealed hemorrhage (e.g., Fig. 2d) and hepatocellular vacuolation in many individuals, and of the two that succumbed at

pyknotic nuclei in a screech-owl that ingested $9.55 \mathrm{ppm}$ DPN for 7 days; e hepatocellular vacuolation and signs of early cell death in the liver of a screech-owl that ingested 22.6 ppm DPN for 7 days; f peracute pericentral hepatocellular necrosis involving much of the liver of a screech-owl that ingested $22.6 \mathrm{ppm}$ DPN for 7 days

$22.6 \mathrm{ppm}$, one owl had evidence of early liver necrosis with hepatocytes that were separating, rounding up, and becoming hypereosinophilic with shrunken dense nuclei (Fig. 2e). The other owl had more advanced peracute necrosis that involved hepatocytes around central veins and extended into the mid-zonal region (Fig. 2f).

Body weight change over the 7-day trial did not differ $(p>0.8)$ among the control and DPN treatment groups (individual values ranged from -15.0 to $+10.1 \mathrm{~g} / 100 \mathrm{~g}$ initial body weight). In general, owls ate each day, with the exception of the individual consuming $22.6 \mathrm{ppm}$ that stopped eating after day 4 and succumbed on day 7 (exhibited mild weight loss, $-8.4 \mathrm{~g} / 100 \mathrm{~g}$ initial body 
Table 1 Toxicity of diphacinone following acute oral exposure in Eastern screech-owls

\begin{tabular}{|c|c|c|c|c|c|c|c|}
\hline \multirow[t]{2}{*}{$\begin{array}{l}\text { Administered } \\
\text { dose }\end{array}$} & \multirow[t]{2}{*}{$\begin{array}{l}\text { Died/ } \\
n \text { dosed }\end{array}$} & \multirow[t]{2}{*}{$\begin{array}{l}\text { Survivors exhibiting } \\
\text { signs of intoxication }\end{array}$} & \multirow[t]{2}{*}{$\begin{array}{l}\text { Total owls } \\
\text { affected } / n\end{array}$} & \multirow[t]{2}{*}{$\begin{array}{l}\text { Prothrombin } \\
\text { time (s) }\end{array}$} & \multirow{2}{*}{$\begin{array}{l}\text { Russell's } \\
\text { Viper venom } \\
\text { time (s) }\end{array}$} & \multicolumn{2}{|c|}{$\begin{array}{l}\text { Liver diphacinone residues } \\
\text { ( } \mu \mathrm{g} / \mathrm{g} \text { wet weight) }\end{array}$} \\
\hline & & & & & & Died & Euthanized (day 8) \\
\hline 0 & $0 / 4$ & 0 & $0 / 4$ & $11.9-14.4$ & $20.9-23.6$ & & $<$ MLOD \\
\hline 266 & $1 / 1$ & - & $1 / 1$ & - & - & 0.948 & \\
\hline 400 & $0 / 2$ & 1 & $1 / 2$ & $15.2,21.9$ & $30.7,47.0$ & & $0.314,0.495$ \\
\hline 600 & $1 / 4$ & 2 & $3 / 4$ & $13.4-27.0$ & $31.7-57.2$ & 3.59 & $0.244,0.247,0.378$ \\
\hline 900 & $0 / 4$ & 1 & $1 / 4$ & $11.0,44.5$ & $51.9,225.2$ & & $0.179,0.247,0.317,0.362$ \\
\hline 1450 & $2 / 4$ & 1 & $3 / 4$ & $19.4,33.2$ & $54.1,55.1$ & $1.00,61.9$ & $0.229,0.695$ \\
\hline
\end{tabular}

MLOD method limit of detection $(0.089 \mu \mathrm{g} / \mathrm{g}$ wet weight $)$

${ }^{a}$ External signs included bruising of skin, and internal signs included hemorrhage in liver, clots in peritoneal cavity, and pale gastrointestinal tract and liver

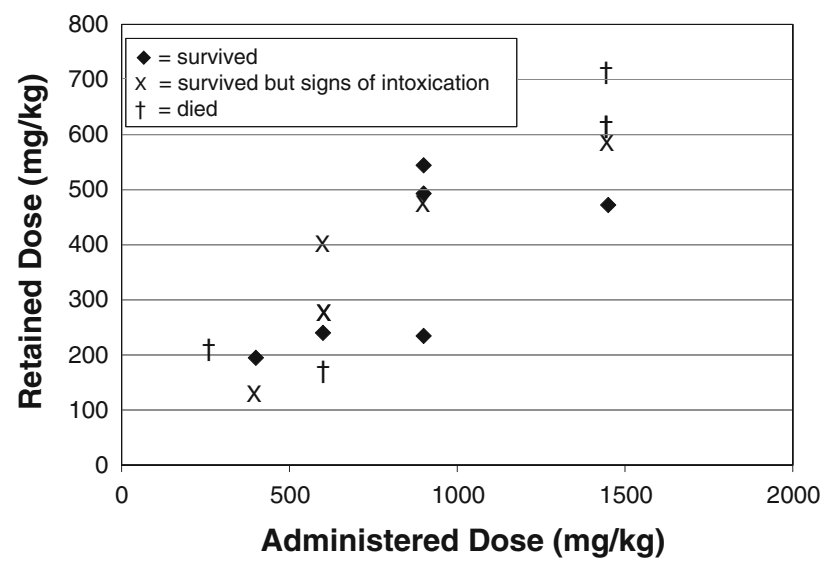

Fig. 3 Relation of acutely administered DPN, retained dose, and signs of intoxication in Eastern screech-owls

weight, but had histological evidence of hemorrhage and liver necrosis).

Hematocrit of control owls ranged from 42 to $55 \%$ (Table 2). Hematocrit appeared to be inversely related to DPN dose (Table 2), although inspection of these data for individual owls revealed that the response was not graded, but rather reflected an increasing number of respondents with low $(<30)$ hematocrit (e.g., at $2.15 \mathrm{ppm}$, hematocrit of one owl was 22, while values for the four other unaffected birds ranged from 39 to 46 ; at $9.55 \mathrm{ppm}$, hematocrit values of two owls were 23 and 26, while values for the three remaining birds ranged from 40 to 44$)$. There was a significant relation $(p<0.025)$ between hematocrit and cumulative DPN dose for the owls that survived the trial $\left(R^{2}=0.40 ; n=19\right)$. Clotting time as assessed by PT and RVVT was prolonged $(p<0.001)$ in owls ingesting DPN compared to controls (Figs. 4, 5), and was well above baseline values measured 10 days before the study. Fibrinogen concentration in these samples exceeded $90 \mathrm{mg} / \mathrm{dl}$.
Diphacinone was detected in the liver of all owls ingesting DPN but not in the 4 control samples that were analyzed (Table 2). Values ranged from 0.473 to $2.21 \mu \mathrm{g} / \mathrm{g}$ (liver tissue of owls that died contained 1.26 and $1.29 \mu \mathrm{g} / \mathrm{g}$ ), and concentrations were similar $(p>0.05)$ among the three DPN treatment groups. The concentration of DPN in liver was related $(p<0.01)$ to the quantity consumed on a per owl $\left(R^{2}=0.40 ; n=20\right)$ and per kg owl $\left(R^{2}=0.35\right.$; $n=20)$ basis.

Risk assessment of dietary exposure to diphacinone

The lowest dietary concentration of DPN fed to screechowls that reduced hematocrit ( 1 of 5 owls) and prolonged clotting time (5 of 5 owls) was $2.15 \mathrm{ppm}$. Based upon food consumption measurements for each owl over the 7-day trial and the actual concentration of DPN in their diet, the lowest-observed-adverse-effect-level (LOAEL) for anemia and coagulopathy for the 7-day cumulative dose averaged $1.68 \mathrm{mg}$ DPN $/ \mathrm{kg}$ owl (i.e., $0.34 \mathrm{mg} / \mathrm{owl}$ ) and for a daily dose averaged $0.24 \mathrm{mg}$ DPN $/ \mathrm{kg}$ owl $/$ day (i.e., $0.049 \mathrm{mg} /$ owl/day) (Table 2). The LOAEL for prolonged PT in the most sensitive individual (i.e., consumed the least amount of DPN that exhibited adverse effects) for the 7-day trial was $1.09 \mathrm{mg}$ DPN $/ \mathrm{kg}$ owl (average daily dose of $0.16 \mathrm{mg} /$ $\mathrm{kg}$ owl/day). The LOAEL for reduced hematocrit in the most sensitive individual for the 7-day trial was $2.52 \mathrm{mg}$ DPN $/ \mathrm{kg}$ owl (average daily dose of $0.36 \mathrm{mg} / \mathrm{kg}$ owl $/$ day). The lowest dietary concentration of DPN that was lethal (2 of 6 birds died) was $22.6 \mathrm{ppm}$. Based upon food consumption measurements and the actual cumulative dietary dose of the most sensitive individual that succumbed (died on day 7 of trial), the lowest lethal dose (LLD) was $5.75 \mathrm{mg}$ DPN $/ \mathrm{kg}$ owl $/ 7$ days (average daily dose of $0.82 \mathrm{mg} / \mathrm{kg}$ owl $/$ day).

As part of a Special Local Needs pesticide registration (Federal Insecticide, Fungicide, and Rodenticide Act 

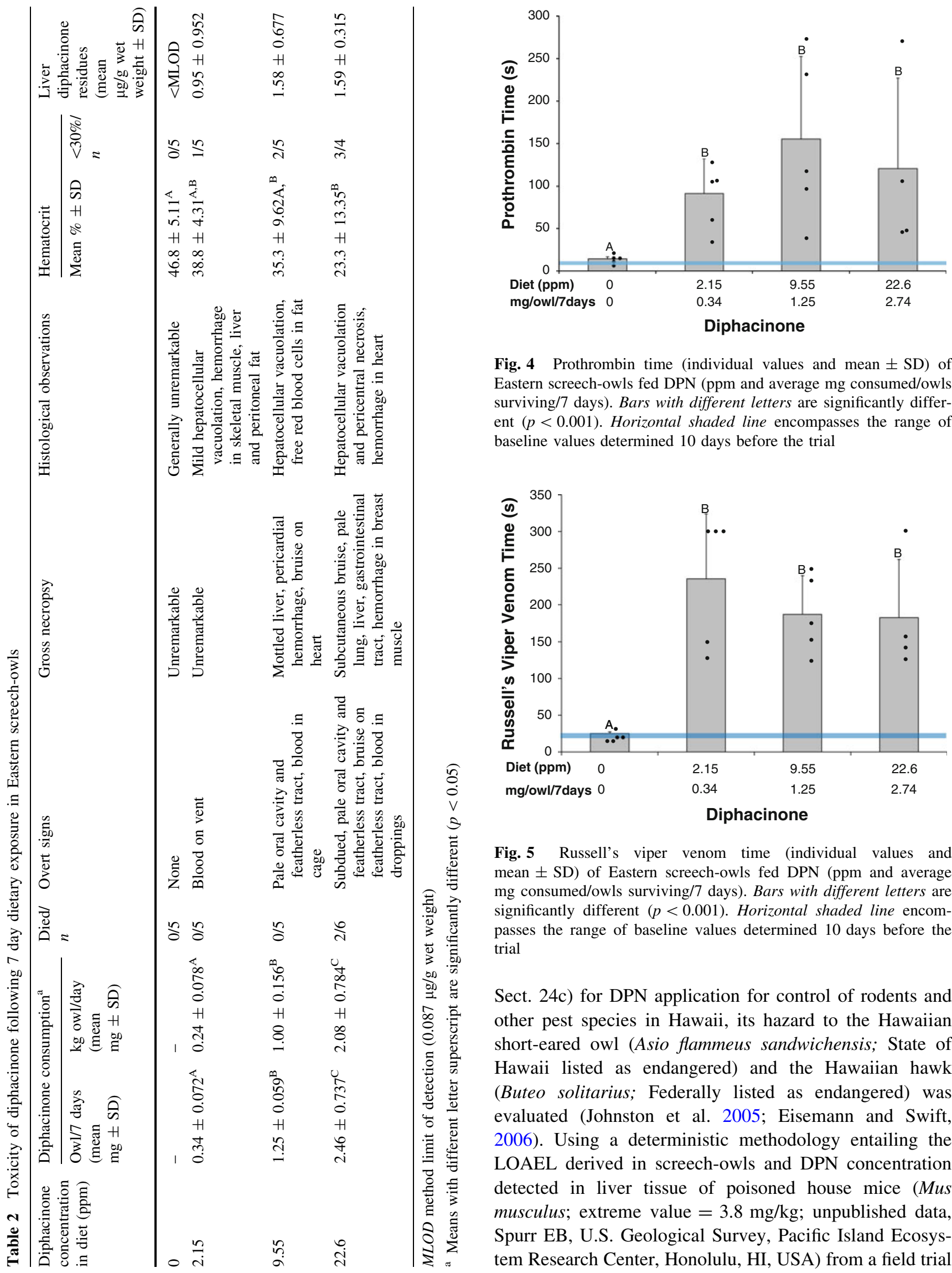

Fig. 4 Prothrombin time (individual values and mean \pm SD) of Eastern screech-owls fed DPN (ppm and average mg consumed/owls surviving/7 days). Bars with different letters are significantly different $(p<0.001)$. Horizontal shaded line encompasses the range of baseline values determined 10 days before the trial

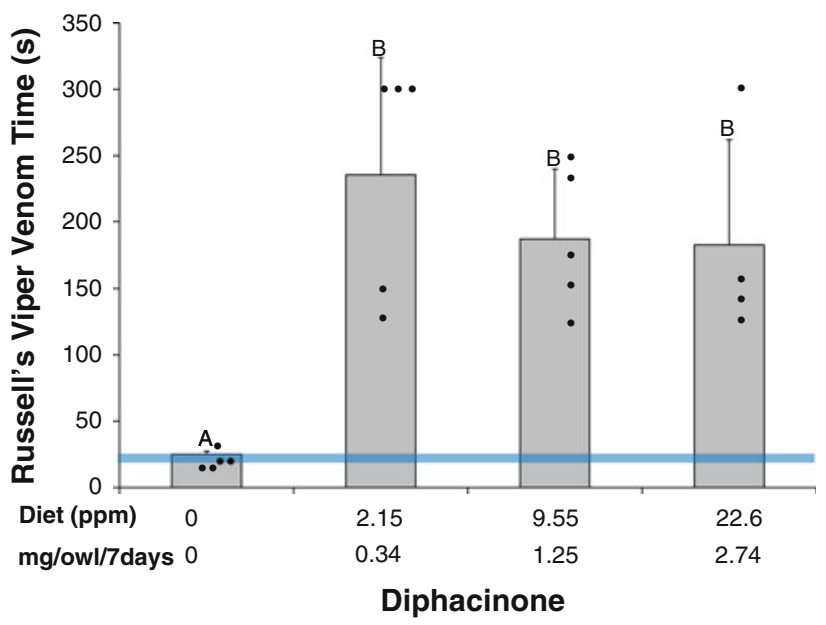

Fig. 5 Russell's viper venom time (individual values and mean $\pm \mathrm{SD}$ ) of Eastern screech-owls fed DPN (ppm and average $\mathrm{mg}$ consumed/owls surviving/7 days). Bars with different letters are significantly different $(p<0.001)$. Horizontal shaded line encompasses the range of baseline values determined 10 days before the trial

Sect. 24c) for DPN application for control of rodents and other pest species in Hawaii, its hazard to the Hawaiian short-eared owl (Asio flammeus sandwichensis; State of Hawaii listed as endangered) and the Hawaiian hawk (Buteo solitarius; Federally listed as endangered) was evaluated (Johnston et al. 2005; Eisemann and Swift, 2006). Using a deterministic methodology entailing the LOAEL derived in screech-owls and DPN concentration detected in liver tissue of poisoned house mice (Mus musculus; extreme value $=3.8 \mathrm{mg} / \mathrm{kg}$; unpublished data, Spurr EB, U.S. Geological Survey, Pacific Island Ecosystem Research Center, Honolulu, HI, USA) from a field trial 
Table 3 Dietary risk of adverse effects in endangered Hawaiian raptors consuming diphacinone-poisoned rodents

\begin{tabular}{|c|c|c|c|c|c|}
\hline Species & $\begin{array}{l}\text { Weight } \\
(\mathrm{kg})\end{array}$ & $\begin{array}{l}\text { Eastern screech-owl LOAEL for } \\
\text { sublethal toxicity }(\mathrm{mg} / \mathrm{kg} / \text { day })^{\mathrm{a}}\end{array}$ & $\begin{array}{l}\text { Sublethal secondary } \\
\text { exposure (g liver/day) }\end{array}$ & $\begin{array}{l}\text { Eastern screech-owl } \\
\operatorname{LLD}(\mathrm{mg} / \mathrm{kg} / \text { day })^{\mathrm{a}}\end{array}$ & $\begin{array}{l}\text { LLD secondary } \\
\text { exposure (g liver/day) }\end{array}$ \\
\hline $\begin{array}{l}\text { Hawaiian } \\
\text { short-eared } \\
\text { owl }\end{array}$ & 0.35 & 0.24 & 22.1 & 0.82 & 75.5 \\
\hline $\begin{array}{l}\text { Hawaiian } \\
\text { hawk }\end{array}$ & 0.45 & 0.24 & 9.0 & 0.82 & 30.8 \\
\hline
\end{tabular}

in Hawaii, the quantity of mouse liver that would have to be consumed by a short-eared owl to evoke sublethal effects would be about $22.1 \mathrm{~g}$ of liver per day for 7 days (Table 3). Likewise, the quantity of liver of poisoned black rats (Rattus rattus; extreme value $=12 \mathrm{mg} / \mathrm{kg}$ ) that would have to be consumed by the Hawaiian hawk to evoke sublethal effects would be about $9.0 \mathrm{~g}$ of liver per day for 7 days (Table 3). If the LOAEL for the most sensitive Eastern screech-owl was substituted in this calculation (i.e., $0.16 \mathrm{mg}$ DPN/kg owl/day), sublethal effects might be evoked in the short-eared owl and hawk consuming as little as $14.4 \mathrm{~g}$ and $5.9 \mathrm{~g}$ of liver per day. Similar calculations using the LLD endpoint in screech-owls suggest that the short-eared owl would have to consume $75.5 \mathrm{~g}$ liver from poisoned house mice per day for a week and the hawk would have to consume $30.8 \mathrm{~g}$ of liver from poisoned black rats per day for a week to evoke mortality (Table 3).

Using the sublethal threshold for anemia and prolonged clotting time $(0.24 \mathrm{mg} / \mathrm{kg} / \mathrm{day})$ and the aforementioned rodent liver residue data in the probabilistic-based exposure model of Johnston and coworkers (Johnston et al. $2005)$, it was determined that a small fraction (1\%) of the population of male Hawaiian short-eared owls would exceed the LOAEL if they consumed more than $3.72 \mathrm{~g}$ of liver per day, and $10 \%$ of the male population would exceed the LOAEL if $19.6 \mathrm{~g}$ of liver from DPN poisoned mice were consumed for 7 days (Fig. 6). A similar probabilistic analysis for male Hawaiian hawks indicated that the LOAEL would be exceeded if greater than $2.73 \mathrm{~g}$ of liver from poisoned rats were consumed for 7 days, and $10 \%$ of the population would exceed this threshold if $16.4 \mathrm{~g}$ of liver from poisoned rats were consumed daily (Fig. 7). If the LOAEL for the most sensitive Eastern screech-owl was substituted (i.e., $0.16 \mathrm{mg}$ DPN/kg owl/ day), sublethal effects (prolonged clotting time) would be evoked in the short-eared owl and hawk consuming as little as $2.5 \mathrm{~g}$ and $1.8 \mathrm{~g}$ of liver per day for 7 days. Similar estimates using the LLD in screech-owls suggest that the short-eared owl would have to consume $12.7 \mathrm{~g}$ of liver

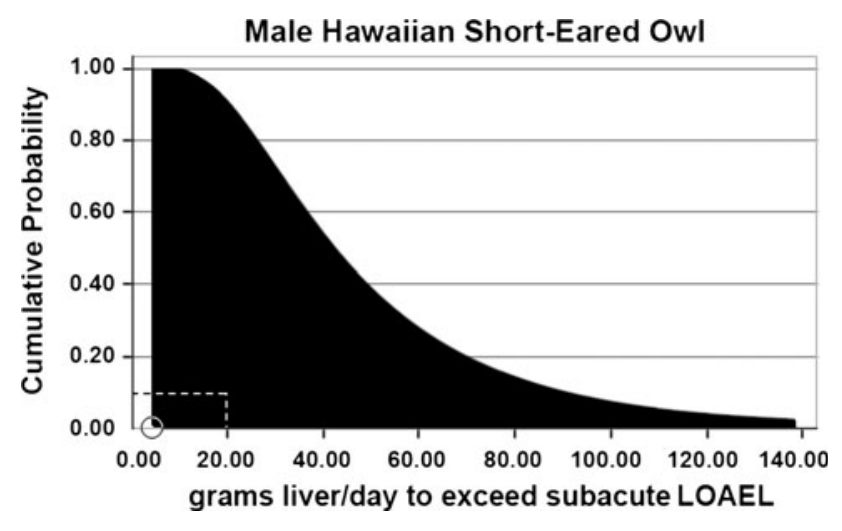

Fig. 6 Cumulative probability curve of exceeding the lowestobserved-adverse-effect-level (LOAEL $=0.24 \mathrm{mg}$ DPN $/ \mathrm{kg}$ owl $/$ day) for prolonged clotting time and anemia of male Hawaiian short-eared owls consuming liver from DPN-poisoned house mice for 1 week. One percent of the population (open circle) would exceed the LOAEL by consuming $3.72 \mathrm{~g} /$ day and $10 \%$ (dashed line) of the population would exceed the LOAEL by consuming $19.6 \mathrm{~g} /$ day

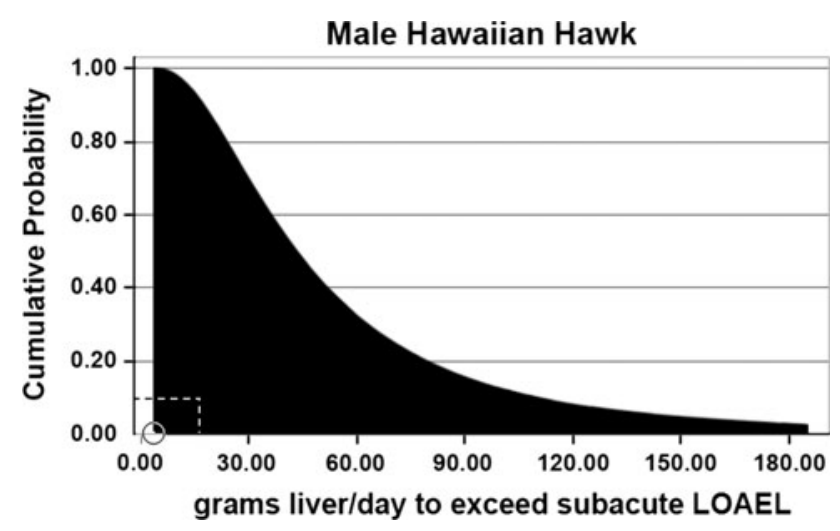

Fig. 7 Cumulative probability curve of exceeding the lowestobserved-adverse-effect-level (LOAEL $=0.24 \mathrm{mg} \mathrm{DPN} / \mathrm{kg}$ owl $/$ day) for prolonged clotting time and anemia of male Hawaiian hawks consuming liver from DPN-poisoned black rats for 1-week. One percent of the population (open circle) would exceed the LOAEL by consuming $2.73 \mathrm{~g} / \mathrm{day}$ and $10 \%$ of the population (dashed line) would exceed the LOAEL by consuming $16.4 \mathrm{~g} /$ day 
from poisoned house mice per day and the hawk would have to consume $9.3 \mathrm{~g}$ of liver from poisoned black rats per day to evoke mortality in a small fraction $(1 \%)$ of the male population of these species (Table 3 ).

\section{Discussion}

Acute oral administration of DPN to Eastern screech-owls evoked overt signs of intoxication, histopathological lesions, and coagulopathy consistent with the mechanism of action of FGARs (i.e., inhibition of vitamin $\mathrm{K} 2$, 3 -epoxide reductase). However, using a relatively small sample size, attempts to develop a dose-response relationship using nominal dose or retained dose (accounting for DPN regurgitated or eliminated in pellets, see Eadsforth et al. 1991; Newton et al. 1994) with the endpoints of mortality, or the combination of overt signs of intoxication plus mortality, proved unsuccessful. This is in contrast to the dose-response relationships for acutely administered DPN in captive American kestrels (Rattner et al. 2011), and for other classes of compounds administered to Eastern screech-owls (e.g., organophosphorus and carbamate insecticides, cyanide; Wiemeyer et al. 1986, 1991).

Both laboratory and operational field trials have demonstrated that FGARs generally require multiple feedings over several days to evoke mortality in target species (Dubock 1982; Ashton et al. 1986; Jackson and Ashton 1992; Ramey et al. 2007). A recent critique on the use of the standardized acute oral avian toxicity test for assessing the hazard of FGARs suggested that the exposure regimen employed to derive an acute oral median lethal dose, and often used to derive toxicity data, pharmacokinetic parameters, and residue threshold concentrations for lethality, differs considerably from the environmentally relevant multiple-feeding exposure scenario required to control rodents in the field (Vyas and Rattner 2011). Thus, FGAR data derived from acute oral exposure studies could provide misleading information for both ecological risk assessments and the interpretation of samples for forensic investigations. For illustrative purposes, in DPN acute oral toxicity studies with Eastern screech-owls (present study) and American kestrels (Rattner et al. 2011), the lowest doses evoking lethality were $171 \mathrm{mg} / \mathrm{kg}$ (retained dose) and $79 \mathrm{mg} / \mathrm{kg}$, respectively. However, in 7-day dietary feeding trials in Eastern screech-owls, the lowest cumulative dose evoking lethality, $5.75 \mathrm{mg} / \mathrm{kg}$, was more than an order of magnitude less than LLD in acute toxicity trials.

Only two other small-scale controlled exposure feeding studies have examined DPN toxicity in raptorial birds. In an often cited trial by Savarie et al. (1979), seven captive golden eagles (Aquila chrysaetos) were fed muscle for 5 or 10 days from sheep (Ovis aries) that had been dosed with DPN $(30 \mathrm{mg} / \mathrm{kg})$, and then the eagles were switched to untreated food for 11 days. Prothrombin time more than doubled at doses as low as $0.11 \mathrm{mg} / \mathrm{kg} /$ day (cumulative dose as low as $0.55 \mathrm{mg} / \mathrm{kg}$ ) (Eisemann and Swift 2006). Two of the eagles (daily doses: 0.22 and $0.14 \mathrm{mg} /$ $\mathrm{kg} /$ day; cumulative doses: 1.08 and $1.38 \mathrm{mg} / \mathrm{kg}$ ) exhibited muscular weakness and extreme ataxia, and one of these bled from wounds on the wings and feet. During days 5-15 of the 21-day trial, four of seven birds (cumulative doses ranging from 1.08 to $2.1 \mathrm{mg} / \mathrm{kg}$ ) had transient decreases in hematocrit (values of 19,31, 31 and 30) compared to the pre-trial control value (i.e., 45). All seven of these eagles recovered by day 21 ( 11 days postdose). In a study by Mendenhall and Pank (1980), three great-horned owls (Bubo virginianus) and one saw-whet owl (Aegolius acadicus) were fed DPN-poisoned mice (Peromyscus maniculatus; $0.01 \%$ DPN bait) for 5 days. An approximation of the cumulative dose received by the owls (i.e., $\mathrm{mg}$ DPN $/ \mathrm{kg}$ owl weight ignoring DPN absorption, metabolism and elimination in the rodents) suggests that hemorrhage and/or lethality occurred when great-horned owls consumed $3-4 \mathrm{mg} / \mathrm{kg}$ and when the saw-whet owl had consumed about $55 \mathrm{mg} / \mathrm{kg}$ (Mendenhall VM, personal communication). Results of the present Eastern screech-owl feeding trial compare favorably with these studies for both sublethal responses (e.g., LOAEL for PT of the most sensitive screech-owl was $0.16 \mathrm{mg} / \mathrm{kg} /$ day versus $0.11 \mathrm{mg} / \mathrm{kg} /$ day for the golden eagle; LOAEL for reduced hematocrit of the most sensitive screech owl was $0.36 \mathrm{mg} / \mathrm{kg} /$ day versus $0.22 \mathrm{mg} / \mathrm{kg} / \mathrm{day}$ for the golden eagle) and for lethality (cumulative LLD in the screechowl was $5.75 \mathrm{mg} / \mathrm{kg}$ versus $3-4 \mathrm{mg} / \mathrm{kg}$ in the greathorned owl). Although DPN toxicity thresholds in owls and the golden eagles are quite comparable, as a group, birds of prey seem to be more vulnerable than other avian feeding guilds to many classes of pollutants (reviewed in Golden and Rattner 2003), including anticoagulant rodenticides. For example, an acute toxicity trial in American kestrels indicated they were 20-30 times more sensitive than bobwhite and mallards (Rattner et al. 2010a, b, 2011), and in the present study, 2 of 6 Eastern screech-owls succumbed following exposure to $22.6 \mathrm{ppm}$ compared to an estimated LC50 of $906 \mathrm{ppm}$ for mallards (Long et al. 1992a) and an LC50 > 5,000 ppm for Northern bobwhite (Long et al. 1992b). Differences in vitamin $\mathrm{K}$ 2,3-epoxide reductase kinetics and inhibition, and rodenticide metabolism and clearance, could contribute to the sensitivity of raptors to anticoagulant rodenticides. Notably, hepatic microsomal hydroxylation rates of the FGAR warfarin in great-horned and snowy owls were recently demonstrated to be $25 \%$ of those 
observed in mallards and only $2 \%$ of those found in domestic chickens (Watanabe et al. 2010).

Pathological lesions and clotting time

Acute oral and short-term dietary DPN exposure of owls often resulted in external evidence of hemorrhage and anemia during the course of these trials, and further indication of hemorrhage was apparent at necropsy. In the dietary study, the severity of rodenticide-induced bleeding was clearly dose-dependent. In both studies, histological observations of bleeding in skeletal muscle, liver, kidney, heart and other tissues, ranging from small foci to broad regions, were detected in some but not all individuals. These observations are consistent with several anticoagulant rodenticide dosing trials in raptors (Savarie et al. 1979; Mendenhall and Pank 1980; Radvanyi et al. 1988; Newton et al. 1990), but do contrast findings of principally microscopic hemorrhage (but not frank external bleeding) in the acute DPN dosing study in American kestrels (Rattner et al. 2011). In the absence of frank external bleeding, observations of depression, weakness and pallor were noted in DPN-dosed kestrels and screech-owls, and are considered key signs of potential rodenticide poisoning (Mount 1988). Heptaocellular vacuolation and necrosis were present in the most severely affected individuals, and have been previously reported in FGAR and SGAR poisoning cases in both birds and mammals (DuVall et al. 1989; Shivaprasad and Galey 2001). Such hepatocellular lesions are suggestive of a metabolic disturbance and hypoxia possibly as a result of anemia. Notably, indandione rodenticides may also be weak uncouplers of oxidative phosphorylation, which could evoke a more direct toxic effect on hepatocytes (van den Berg and Nauta 1975; Pelfrene 1991). Hemorrhage in major organs and blood vessels was a likely contributor to death, and in some instances, the definitive cause of mortality.

Anticoagulant rodenticides are vitamin $\mathrm{K}$ antagonists that irreversibly inhibit the epoxide reductase responsible for the recycling of oxidized vitamin $\mathrm{K}$ to its biologically active reduced form. Vitamin $\mathrm{K}$ serves as a cofactor in the post-translational carboxylation of the prothrombin group of serine protease coagulation factors (Factors II, VII, IX and $\mathrm{X}$ ), and without carboxylation, clotting factors do not assemble on cell surfaces to form active coagulation complexes (Mount and Feldman 1983; Furie et al. 1999). The lag time between anticoagulant exposure and coagulopathy reflects the clearance of carboxylated clotting factors II, VII, IX and X from blood (half-lives of 2-120 h in humans; Chan et al. 1987), and the increasing concentration of circulating des-carboxy dysfunctional clotting factors that result in prolonged clotting time. As little as a $25 \%$ increase in PT has been described as being suggestive of anticoagulant exposure (Shlosberg and Booth 2006). In sublethal DPN dosing studies in American kestrels $(50 \mathrm{mg} /$ $\mathrm{kg}$ administered orally as a single dose or divided dose in $24 \mathrm{~h}$ ), both PT and RVVT were found to be prolonged between 48 and $96 \mathrm{~h}$ after administration of DPN (often corresponding to onset of overt toxicity and lethality), and then returned to baseline by day 7 post-dose (Rattner et al. 2010a, 2011). Unlike kestrels, coagulopathy persisted 7 days after acute exposure of Eastern screech-owls, perhaps because DPN doses were substantially greater in owls (retained doses ranged from 130 to $718 \mathrm{mg} / \mathrm{kg}$ ) compared to kestrels $(50 \mathrm{mg} / \mathrm{kg}$ ). Prolonged clotting time was clearly apparent in screech-owls ingesting small quantities of DPN for 7 days (as low as $0.16 \mathrm{mg} / \mathrm{kg} /$ day; cumulative dose of $1.09 \mathrm{mg} / \mathrm{kg}$ that corresponds to $2.18 \%$ of the acute dose in kestrels). Although a number of studies have examined FGAR (Veltmann et al. 1981; Martin et al. 1994; Massey et al. 1997) and SGAR (Bailey et al. 2005; Webster 2009) effects on clotting time in birds, dietary feeding trials have yet to be conducted that examine the time course for the onset of coagulopathy and a no-observed-adverse-effectlevel for coagulopathy in raptors. Because raptors seem to be more sensitive than avian test species routinely used in toxicity test (e.g., mallard, quail, chicken), such data would be particularly valuable for anticoagulant rodenticide risk assessments.

\section{Tissue residues}

Stringent standards for diagnosis of anticoagulant rodenticide poisoning entails a combination of exposure history, clinical signs (hemorrhage), laboratory diagnostics (e.g., reduced hematocrit, prolonged clotting time, and tissue residues), and tissue lesions (Shlosberg and Booth 2006). Rarely, are all such data available for a suspect incident. Threshold concentrations of FGARs in tissues that are associated with adverse effects in non-target birds have yet to be established. In the most definitive field situation involving DPN, subcutaneous and inter- and intramuscular hemorrhage, and hepatic residues of $0.26 \mu \mathrm{g} / \mathrm{g}$ were detected in a snowy owl that had established temporary residence at a site using DPN for rodent control (Stone et al. 1999). In other cases involving raptors, DPN was detected in liver $(0.081-0.34 \mu \mathrm{g} / \mathrm{g})$, but could not be definitively implicated in mortality incidents involving raptors (e.g., red-tailed hawk, Cooper's hawk, barn owl) (Stone et al. 2003; Pitt et al. 2005). In acute toxicity studies in kestrels, liver concentrations of birds which succumbed ranged from 13.4 to $56.3 \mu \mathrm{g} / \mathrm{g}$ (liver at LLD contained $3.59 \mu \mathrm{g} / \mathrm{g}$ ), survivors had $<1 \mu \mathrm{g} / \mathrm{g}$, and some individuals exhibited histopathological lesions at concentrations as low as $0.263 \mu \mathrm{g} / \mathrm{g}$ (Rattner et al. 2011). Similarly, in the acute toxicity study in screech-owls hepatic DPN levels in the 
livers of birds that died ranged from 0.94 to $61.9 \mu \mathrm{g} / \mathrm{g}$ (liver at LLD contained $12.6 \mu \mathrm{g} / \mathrm{g}$ ), while survivors had residues $<0.70 \mu \mathrm{g} / \mathrm{g}$. The range and magnitude of values in dead kestrels and screech-owls reflect the environmentally unrealistic mode of exposure (acute oral dose rather than low-dose multiple day exposure), and are not suitable for establishing cause of death in non-target wildlife (Vyas and Rattner 2011). In contrast, residue concentrations in liver of screech-owls ingesting comparatively low levels of DPN for 7 days, and exhibiting coagulopathy, anemia, and histopathological lesions consistent with anticoagulant rodenticide poisoning, contained $0.473-2.21 \mu \mathrm{g} / \mathrm{g}$, with levels for the two owls that died $(1.26$ and $1.29 \mu \mathrm{g} / \mathrm{g})$ within this range. It is unfortunate that even lower dietary feeding levels were not included in the present study so a residue concentration at the threshold of adverse effects (overt signs, coagulopathy, tissue lesions) could have been estimated. Tissue concentrations of single-dose long biological half-life SGARs (e.g., brodifacoum, bromadiolone, difethialone) associated with toxicity and death are often cited as being $>0.1-0.2 \mu \mathrm{g} / \mathrm{g}$ (Newton et al. 1999), although a recent probabilistic evaluation for some predatory birds suggests the likelihood of toxicosis is $<0.1 \mu \mathrm{g} / \mathrm{g}$ (Thomas et al. 2011).

\section{Risk assessment}

A considerable effort has been expended on assessing the hazard of DPN to non-target wildlife as part of an application for a Special Local Needs pesticide registration for its broadcast application for control of rodents and other pests in Hawaii (Johnston et al. 2005; Eisemann and Swift 2006). These assessments concluded that the risk associated with acute exposure to DPN would be minimal for several endangered species (e.g., black-faced honeycreeper, Melamprosops phaeosoma, Hawaiian short-eared owl, and Hawaiian hawk), although the Hawaiian crow (Corvus hawaiiensis) was identified as possibly being at risk of lethal effects from direct ingestion of bait (primary exposure). However, applying recent data from a DPN dose-response curve for lethality in American kestrels in a probability-based 1-day exposure model, it was predicted that a small fraction of Hawaiian short-eared owls (weighing about $350 \mathrm{~g}$ ) and hawks (weighing about $450 \mathrm{~g}$ ) would be at risk (50\% of males would have a $1 \%$ probability of mortality) if they consumed as little as $3-5 \mathrm{~g}$ of liver from DPN-poisoned rodents (Rattner et al. 2011). Although such a response would have little impact of population viability, it may not be considered acceptable for a threatened or endangered species. Based on the available data, the aforementioned risk assessments focused principally on acute single-day exposure, but acknowledged the possibility of sublethal effects through repeated ingestion of invertebrates or rodents (secondary exposure).

First-generation anticoagulant baits (e.g., DPN, chlorophacinone) require multi-day feedings to evoke adverse effects and mortality to target species, and accordingly the potential risk to non-target birds and mammals increase with repetitive exposure. Using data generated in the 7-day feeding trial in screech-owls and the probability-based model, endangered Hawaiian short-eared owls and hawks would have to consume only 2.73 and $3.72 \mathrm{~g}$ of liver per day from poisoned rodents for several days to exceed a conservative LOAEL for prolonged clotting time and anemia (i.e., $0.24 \mathrm{mg} / \mathrm{kg} /$ day). These quantities of liver are similar to our initial deterministic estimates using the LOAEL for prolonged clotting time (Rattner et al. 2011) derived from the study in golden eagles (Savarie et al. 1979). However, because a no-observed-adverse-effectlevel was not determined for coagulopathy in the screechowl feeding trial, it is certainly possible that effects on clotting time may occur at even lower levels of exposure, and thus could have ramifications for wildlife in general, and not just threatened and endangered raptors.

The objectives of rodenticide application differ among its uses in urban/suburban settings, in agriculture, and in remote island restoration projects. They range from simple control of rodent pest species to their outright eradication for ecosystem restoration and seabird population recovery. Repeated consumption of small quantities of FGARs by nontarget wildlife can evoke sublethal effects (e.g., coagulopathy, pathologic lesions) and outright mortality. Sublethal effects are probable in seasonal rodent control operations (i.e., agricultural and commensal) and for short periods following large-scale eradication operations on islands. However, in some agricultural situations (e.g., macadamia orchards in Hawaii) exposure and risk of non-target wildlife may be low (Lindsey and Mosher 1994) as poisoned-rodents succumb in borrows (Tobin et al. 1996) and are not readily available for consumption by raptors. Clearly, natural resource managers must carefully weigh the costs and benefits of pest control and pest eradication activities.

Acknowledgments The authors wish to thank Wayne C. Bauer and Mary E. Maxey of the Patuxent Wildlife Research Center for animal care, Dr. Natalie Karouna-Renier of Patuxent for assistance with sexing owls, Dr. Marjory B. Brooks of the Comparative Coagulation Laboratory, Animal Health Diagnostic Center of Cornell University for guidance on the development of clotting assays, and Drs. Gary H. Heinz and Nimish B. Vyas for reviewing a draft of this manuscript. This work was supported by the U.S. Department of Agriculture, U.S. Geological Survey and a grant from the California Department of Food and Agriculture Vertebrate Pest Control Research Advisory Committee (agreement 07-0832). Any use of trade, product or firm names is for descriptive purposes only and does not imply endorsement by the U.S. government. 


\section{References}

Albert CA, Wilson LK, Mineau P, Trudeau S, Elliott JE (2009) Anticoagulant rodenticides in three owl species from western Canada, 1988-2003. Arch Environ Contam Toxicol 58:451-459

Ashton AD, Jackson WB, Peters H (1986) Comparative evaluation of LD50 values for various anticoagulant rodenticides. Trop Pest Manage 32:187-197

Bailey C, Fisher P, Eason CT (2005) Assessing anticoagulation resistance in rats and coagulation effects in birds using smallvolume blood samples. Sci Conserv 249:5-22

Baldwin RA, Salmon TP (2011) The facts about rodenticides. Wildl Prof 5:50-53

Brubaker JL, Karouna-Renier NK, Chen Y, Jenko K, Sprague DT, Henry PFP (2011) A noninvasive, direct real-time PCR method for sex determination in multiple avian species. Mol Ecol Res $11: 415-417$

Chan E, Aarons L, Serlin M, Breckenridge A, Rowland M (1987) Inter-relationship among individual vitamin K-dependent clotting factors at different levels of anticoagulation. $\mathrm{Br} \mathrm{J}$ Clin Pharm 24:621-625

Dubock AC (1982) Pulsed baiting - a new technique for high potency, slow acting rodenticides. Proc Vert Pest Conf 10:123136

DuVall MD, Murphy MJ, Ray AC, Reagor JC (1989) Case studies on second-generation anticoagulant rodenticide toxicities in nontarget species. J Vet Diagn Invest 1:66-68

Eadsforth CV, Dutton AJ, Harrison EG (1991) A barn owl feeding study with $\left[{ }^{14} \mathrm{C}\right]$ flocoumafen-dosed mice: validation of a noninvasive method for monitoring exposure of barn owls to anticoagulant rodenticides in their prey. Pestic Sci 32:105-119

Eason CT, Spurr EB (1995) Review of the toxicity and impacts of brodifacoum to non-target wildlife in New Zealand. NZ J Zool 22:371-379

Eason CT, Murphy EC, Wright GRG, Spurr EB (2002) Assessment of risks of brodifacoum to non-target birds and mammals in New Zealand. Ecotoxicol 11:35-48

Eisemann JD, Swift CE (2006) Ecological and human health hazards from broadcast application of $0.005 \%$ diphacinone rodenticide baits in native Hawaiian ecosystems. Proc Vert Pest Conf 22:413-433

Erickson W, Urban D (2004) Potential risks of nine rodenticides to birds and nontarget mammals: A comparative approach. EPA P.2004.27 A. Office of Prevention, Pesticides and Toxic Substances, U.S. Environmental Protection Agency, Washington, DC. http://pi.ace. orst.edu/search/getDocketDocument.s?document=EPA-HQ-OPP2006-0955-0005. Accessed 15 July 2011

Furie B, Bouchard BB, Furie BC (1999) Vitamin K-dependent biosynthesis of $\gamma$-carboxyglutamic acid. Blood 93:1798-1808

Golden NH, Rattner BA (2003) Ranking terrestrial vertebrate species for utility in biomonitoring and vulnerability to environmental contaminants. Rev Environ Contam Toxicol 176:67-136

Howald GR, Mineau P, Elliott JE, Cheng KM (1999) Brodifacoum poisoning of avian scavengers during rat control on a seabird colony. Ecotoxicol 8:431-447

Jackson WB, Ashton AD (1992) A review of available anticoagulants and their use in the United States. Proc Vert Pest Conf $15: 156-160$

Johnston JJ, Pitt WC, Sugihara RT, Eisemann JD, Primus TM, Holmes MJ, Crocker J, Hart A (2005) Probabilistic risk assessment for snails, slugs, and endangered honeycreepers in diphacinone rodenticide baited areas on Hawaii, USA. Environ Toxicol Chem 24:1557-1567

Lambert O, Pouliquen H, Larhantec M, Thorin C, L'Hostis M (2007) Exposure of raptors and waterbirds to anticoagulant rodenticides (difenacoum, bromadiolone, coumatetralyl, coumafen, brodifacoum): epidemiological survey in Loire Atlantique (France). Bull Environ Contam Toxicol 79:91-94

Lima LL, Salmon TP (2010) Assessing some potential environmental impacts from agricultural anticoagulant uses. Proc Vert Pest Conf 24:199-203

Lindsey GD, Mosher SM (1994) Tests indicate minimal hazard to 'Io from diphacinone baiting. Hawaii's Forest Wildl 9:1-3

Lock J (2006) Eradication of brown rats Rattus norvegicus and black rats Rattus rattus to restore breeding seabird populations on Lundy Island, Devon, England. Conserv Evid 3:111-113

Long RD, Foster J, Hoxter KA, Smith GJ, Campbell SM (1992a) Diphacinone technical: a dietary LC50 study with the mallard. Project 284-102B. Conducted by Wildlife International, Ltd. Submitted by Bell Laboratories, Inc., Madison, WI. EPA MRID 424088-02

Long RD, Foster J, Hoxter KA, Smith GJ, Campbell SM (1992b) Diphacinone technical: a dietary LC50 study with northern bobwhite. Project 284-101A. Conducted by Wildlife International, Ltd. Submitted by Bell Laboratories, Inc., Madison, WI. EPA MRID 424088-02. EPA MRID 424088-01

Luna LG (1968) Manual of histological staining methods of the Armed Forces Institute of Pathology, 3rd edn. McGraw Hill, New York

Martin GR, Kirkpatrick WE, King DR, Robertson ID, Hood PJ, Sutherland JR (1994) Assessment of the potential toxicity of an anticoagulant, pindone (2-pivalyl-1,3-indandione), to some Australian birds. Wildl Res 21:85-93

Massey G, Valutis L, Marzluff J (1997) Secondary poisoning effects of diphacinone on Hawaiian crows: a study using American crows as surrogates. Report to the U.S. Fish and Wildlife Service Pacific Islands Office. Sustainable Ecosystems Institute, Meridian

Mendenhall VM, Pank LF (1980) Secondary poisoning of owls by anticoagulant rodenticides. Wildl Soc Bull 8:311-315

Mount ME (1988) Diagnosis and therapy of anticoagulant rodenticide intoxications. Vet Clin N Am: Small Anim Pract 18:115-130

Mount ME, Feldman BF (1983) Mechanism of diphacinone rodenticide toxicosis in the dog and its therapeutic implications. Am J Vet Res 44:2009-2017

Newton I, Wyllie I, Freestone P (1990) Rodenticides in British barn owls. Environ Pollut 68:101-117

Newton I, Wyllie I, Gray A, Eadsforth CV (1994) The toxicity of the rodenticide flocoumafen to barn owls and its elimination via pellets. Pestic Sci 41:187-193

Newton I, Shore RF, Wyllie I, Birks JDS, Dale L (1999) Empirical evidence of side-effects of rodenticides on some predatory birds and mammals. In: Cowan DP, Feare CJ (eds) Advances in vertebrate pest management. Filander Verlag, Furth, pp 347-367

Pelfrene AF (1991) Synthetic organic rodenticides. In: Hayes WJ Jr, Laws ER Jr (eds) Handbook of pesticide toxicology, Volume 3: classes of pesticides. Academic Press, San Diego, pp 1271-1316

Pitt WC, Eisemann JD, Swift CE, Sugihara RT, Dengler-Germain B, Driscoll L (2005) Diphacinone residues in free-ranging wild pigs following aerial broadcast of a rodenticide bait in a Hawaiian forest. Unpublished Report QA-1077, National Wildlife Research Center, Fort Collins, CO

Radvanyi A, Weaver P, Massari C, Bird D, Broughton E (1988) Effects of chlorophacinone on captive kestrels. Bull Environ Contam Toxicol 41:441-448

Ramey CA, Matschke GH, Engeman RM (2007) Chlorophacinone baiting for Belding's ground squirrels. In: Nolt, A, Stalman DH (eds) Proceedings of the 12th wildlife damage management conference, Corpus Christi, TX, pp 526-537

Rattner BA, Horak KE, Warner SE, Day DD, Johnston JJ (2010a) Comparative toxicity of diphacinone to northern bobwhite 
(Colinus virginianus) and American kestrels (Falco sparverius). Proc Vert Pest Conf 24:146-152

Rattner BA, Horak KE, Warner SE, Johnston JJ (2010b) Acute toxicity of diphacinone in Northern bobwhite: effects on survival and blood clotting. Ecotoxicol Environ Saf 73:1159-1164

Rattner BA, Horak KE, Warner SE, Day DD, Meteyer MU, Volker SF, Eisemann JD, Johnston JJ (2011) Acute toxicity, histopathology, and coagulopathy in American kestrels (Falco sparverius) following administration of the rodenticide diphacinone. Environ Toxicol Chem 30:1213-1222

Savarie PJ, Hayes DJ, McBride RT, Roberts JD (1979) Efficacy and safety of diphacinone as a predacide. In: Kenaga EE (ed) Avian and Mammalian Wildlife Toxicology. STP 693 American Society for Testing Materials, Philadelphia, PA, pp 69-79

Shivaprasad HL, Galey F (2001) Diphacinone and zinc phosphide toxicity in a flock of peafowl. Avian Pathol 30:599-603

Shlosberg A, Booth L (2006) Veterinary and clinical treatment of vertebrate pesticide poisoning - a technical review. Landcare Research, Lincoln, NZ

Smith DG, Shiinoki EK, VanderWerf EA (2006) Recovery of native species following rat eradication on Mokoli'i Island, O'ahu, Hawai'i. Pacif Sci 60:299-303

Stone WB, Okoniewski JC, Stedelin JR (1999) Poisoning of wildlife with anticoagulant rodenticides in New York. J Wildl Dis 35:187-193

Stone WB, Okoniewski JC, Stedelin JR (2003) Anticoagulant rodenticides and raptors: recent findings from New York, 1998-2001. Bull Environ Contam Toxicol 70:34-40

The Ornithological Council (2010) The Rat Island eradication project: a critical evaluation of nontarget mortality. http://alaska.fws.gov/ ratislandreview-final.pdf. Accessed 15 July 2011

Thomas PJ, Mineau P, Shore RF, Champoux L, Martin PA, Wilson LK, Fitzgerald G, Elliott JE (2011) Second generation anticoagulant rodenticides in predatory birds: probabilistic characterisation of toxic liver concentrations and implications for predatory bird populations in Canada. Environ Int 37:914-920

Tobin ME, Sugihara RT, Koehler AE, Ueunten GR (1996) Seasonal activity and movements of Rattus rattus (Rodentia, Muridae) in a Hawaiian macadamia orchard. Mammalia 60:3-13

Towns DR, Broome KG (2003) From small Maria to massive Campbell: forty years of rat eradications from New Zealand islands. NZ J Zool 30:377-398
US Environmental Protection Agency (2006) Impact assessment for proposed mitigation decision. www.regulations.gov/search/Regs/ home.html\#documentDetail?R=09000064801f4cef. Accessed 15 July 2011

US Environmental Protection Agency (2008) Risk mitigation decision for ten rodenticides. www.epa.gov/pesticides/reregistration/ rodenticides/finalriskdecision.htm. Accessed 15 July 2011

van den Berg G, Nauta WT (1975) Effects of anti-inflammatory 2-aryl-1,3-indandiones on oxidative phosphorylation in rat liver mitochondria. Biochem Pharmacol 24:815-821

Veltmann JR, Ross E Jr, Olbrich SE (1981) The physiological effects of feeding warfarin to poultry. Poult Sci 60:2603-2611

Vyas NB, Rattner BA (2011) Critique on the use of the standardized avian acute oral toxicity test for first generation anticoagulant rodenticides. Human Ecol Risk Assess (in press)

Walker LA, Turk A, Long SM, Wienburg CL, Best J, Shore RF (2008) Second generation anticoagulant rodenticides in tawny owls (Strix aluco) from Great Britain. Sci Total Environ 392:93-98

Watanabe KP, Saengtienchai A, Tanaka KD, Ikenaka Y, Ishizuka M (2010) Comparison of warfarin sensitivity between rat and birds species. Comp Biochem Physiol 152C:114-119

Webster KH (2009) Validation of a prothrombin time (PT) assay for assessment of brodifacoum exposure in Japanese quail and barn owls. Master's Thesis, Simon Fraser University

Whitworth DL, Carter HR, Young RJ, Koepke JS, Gress F, Fangman S (2005) Initial recovery of Xantu's murrelets following rat eradication on Anacapa Island, California. Mar Ornithol 33:131137

Wiemeyer SN (1987) Propagation of captive Eastern screech-owls. J Raptor Res 21:49-56

Wiemeyer SN (2010) Use of captive Eastern screech-owls (Megascops asio) as a wildlife model. J Raptor Res 44:251-252

Wiemeyer SN, Sparling DW (1991) Acute toxicity of four anticholinesterase insecticides to American kestrels, Eastern screech-owls and Northern bobwhites. Environ Toxicol Chem 10:1139-1148

Wiemeyer SN, Hill EF, Carpenter JW, Krynitsky AK (1986) Acute oral toxicity of sodium cyanide in birds. J Wildl Dis 22:538-546 